\title{
Cost Efficiency of Ethiopian Banks
}

\author{
Tesfaye Boru Lelissa ${ }^{1}$ and Abdurezak Mohammed Kuhil ${ }^{2}$
}

\begin{abstract}
The study has explored the efficiency level of banks using cost models. It has used the Data Envelopment Analysis score to examine the efficiency level of banks under both constant and return of scale. In addition, it has explored the scale efficiency of all the models with a statistical test on the significance of variation among Ethiopian Banks. The study finds that banks efficiency level has witnessed a wide variation across various bank groupings. The study has also found outs that the state banks efficiency has been consistently on the efficiency frontier reflecting the high dominance of the banks in the Ethiopian banking system. In addition, the study finds that the small private banks efficiency is growing overtime while the middle size private banks are facing difficulty to improve their level of efficiency. The parametric and nonparametric tests also witness that state and private banks possess different management and technology capabilities. This shows that despite the scale advantage the state banks have, the difference in their management and technology capabilities has contributed for better efficiency performances. On the other front, the statistical test on efficiency determinants shows that deposit growth rate, loan size and earning asset growth are positively and significantly related to efficiencies. Nevertheless, branch size and fixed asset growth rate are negatively and insignificantly related to efficiencies. Consistent to such finding, the benchmarking practice suggests that banks holding excessive deposits limiting their intermediation activities are disadvantaged to count on their efficiency performances. Some of the results from this section of the study such as top efficiency score of state banks and efficiency determinants are unexpected and are explained further in the qualitative study as to their reasons.
\end{abstract}

Keywords: Cost, Efficiency, Ethiopian Banks, DEA

https://dx.doi.org/10.4314/ejeb.v6i2.1

\footnotetext{
${ }^{1}$ PhD Candidate, UNISA

${ }^{2}$ PhD, Assistant Professor of Business Leadership, School of Commerce, College of Business and Economics, AAU, Ethiopia, Email: m.abdurezak@yahoo.com
} 
Cost Efficiency of Ethiopian Banks

\section{Introduction}

Efficiency is producing the right goods/services of the right quality at the right cost. It is the success with which a firm uses its resources to produce output of a given quality (Farrell, 1957). Theoretically, a firm is fully efficient if it produces the output level and mix that maximizes profits and minimizes possible costs. The desirability of efficiency cannot be questioned, however, it may be difficult to achieve it since the planning and forethoughts of the managers responsible for production may not be perfect. In addition, the coordination of the complex operations may be difficult and inadequate and the knowledge on the current practice as well as of the factor prices may not be precise. All these are essential requirements for the achievement of the productive efficiency.

A broader concept that takes core of productive efficiency is the economic efficiency that may also be called business efficiency from a firm's point of view. The proportions on which the concept of economic efficiency depends on: i) resources at disposal of the firm are scarce and ii) they can be put to alternative uses, human capital, machine, materials, finance and time are the scarce resources from which one can produce. Given the scarcity these resources and their alternative uses, it is quite natural for a rational firm to obtain the best from them (Barthwal, 1984). Most importantly banks need to be efficient as they are key players in the financial system that makes money out of efficient operations. The performance in the market basically is the result of the flow from the system in terms of its pricing efficiency and flexibility to adapt to changing situation. The basic aim of the study is to explore the efficiency level and variation among Ethiopian banks and point out the major factors impacting efficiency of banks. It has used a long period data (19992015) and applies a DEA approach to measure the cost efficiency.

\section{Literature}

\subsection{Efficiency}

According to Farrell (1957), overall economic efficiency is composed of two components, i.e. technical efficiency and allocative efficiency. In other words, economic efficiency refers to the combination of technical and allocative efficiency (Coelli et al, 1998). Economic efficiency incorporates efficient selection of goods to be produced, efficient allocation of resources in the production of these goods, efficient choice of the methods of production and efficient allotment of the goods produced among the consumers. Economists 
argue that correct applications of the economic principles will bring about optimal efficiency in the allocation and utilization of all resources, their products and in competition with all other desires of the community.

The neoclassical assumes that producers in an economy always have an internal efficiency, that is, they are producing at their production frontier (allocative efficiency) with maximum output for given inputs (technical efficiency) and, therefore, are cost minimizers. The assumption of perfect internal organizational operations that assumes: no coordination failure, no prisoners dilemma and no market failure, can be considered to be dubious given the fact that performance indicators show inefficiency. This means, in reality however it remains apparent that two alike firms might not produce the same output. That means there will be a difference in cost and profit. This difference in output, cost and profit could be explained in terms of technical and allocative inefficiencies and same unforeseen exogenous shocks. Based on the ideas of Debreu (1951) and Farrell (1957), who built the standard framework of productive efficiency (production frontier), overall economic efficiency can be decomposed into scale efficiency, scope efficiency, pure technical efficiency and allocative efficiency.

\subsubsection{Technical Efficiency}

Technical efficiency in a production unit refers to the achievement of the maximum potential output from given amounts of factor inputs taking into account physical production relationships (Farrell, 1957). Technical efficiency is most frequently associated with the role of management in the production process. For instance, Liebenstein (1966) has argued that firms may fail to produce on the outer boundary of their production surface due to the structure of preferences of managers and workers, giving rise to variations in the level of "X efficiency". It is also doing a task in the cheapest possible way that is producing a given level of output from the lowest possible combination of inputs or producing the maximum output given the level of inputs employed. It reflects the ability of firm or decision making unit to attain the maximum output from a given set of input. Thus, a technically efficient production could produce the same output with less of at least one input, or could use the same input to produce more output (Green, 1993). The level of technical efficiency of a particular firm is characterized by the relationship between observed production and some ideal or potential production. The measurement of firm's specific technical efficiency is based upon deviations of observed output from the best production of efficient frontier. If a firm's actual production point lies 
on the frontier, it is perfectly efficient. If it lies below the frontiers, then it is technically inefficient.

\subsubsection{Allocative Efficiency}

Allocative efficiency, or as Farrell called it price efficiency, refers to the ability of a firm to choose the optimal combination of inputs given input prices (Farrell, 1957). If a firm realizes both technical and allocative efficiency, it is then cost efficient (overall efficient). Allocative efficiency measures the skills in achieving the best combination of inputs by taking into account their relative prices or produces the right mix of outputs given the set of prices (Kumhaker and Hevell, 2000). It reflects the capability of a firm to utilize input in optimal proportion, given their respective prices and the production technology. In other words, allocative efficiency refers to whether inputs for a given level of output and set of input prices are chosen to minimize the cost of production; assuming that the firm being examined is already fully technically efficient. It operates on the least cost expansion path, i.e. the point where the marginal rate of technical substitution is equal to input price ratio. This is very important when one input can be substituted for another in the process of production.

\subsubsection{Scale Efficiency}

Scale Efficiency often arises from the ability of large firms to allocate fixed costs such as advertising expenses or cost of technology across a greater volume of output. It also shows whether the decision-making units (e.g. banks) operate at the minimum of their long run average cost curve. It focuses on technical efficiency which is the ability of a bank to produce maximal output from a given set of inputs over a certain time period (Adongo et al., 2005). Scale economies are usually measured using data on all banks in the sample rather than just using the data on all of the banks. Scale Economies theoretically apply only to the production possibilities frontiers where firms are fully X-Efficient and minimize costs for every scale of output (Berger and Humphrey, 1994).

\subsubsection{Scope Efficiency}

Scope efficiency may result from sharing information such as knowledge of customer's habits across products line. It refers to change in product mix related to cost. It occurs when it is more economical to produce two or more products jointly in a single production unit than to produce the products in separate specializing firms. Scope economies could emanate from two sources: i) spreading of fixed cost over an expanded product mixes and ii) cost complementarities in producing different products. Spreading fixed cost occurs, for example, when the fixed capital of a bank or its branches is more 
Cost Efficiency of Ethiopian Banks

fully utilized by issuing many types of deposits to local residents than building separate offices to fulfill the separate demands for transactions accounts, saving accounts, consumer loans and business loans. Such economical spreading of costs occur to the extent that the production of different types of services requires much the same type of computer, accounting system and other fixed inputs of a branch and there is insufficient local demand to justify a full specialized branch for each of the services. In contrast, cost complementary between deposits and loans occur, for example, when the payment flow information developed in producing deposit services is used to reduce the costs of acquiring credit information and monitoring loans to the same customer. However, there is problem in applying the translog cost/profit function or other multiplicative specification to evaluate scope economies.

\subsubsection{X-Efficiency}

Leibenstin (1966) was the first to introduce the concept of X-inefficiency. He defined it as the loss at which a bank is operating (deviation from the optimum). X-inefficiency is an intra-firm inefficiency or the deviation from the production efficient frontier which depicts the maximum attainable output for a given level of input. This inefficiency can arise from management practice and the environment. X-inefficiency reflects the differences in managerial ability to control cost and/or maximize profits but not suboptimal economies of scale or scope. It has been linked to managerial quality. Empirical X-inefficiency is a measure of how banks utilize their inputs to produce a given level of output. Berger et. al., (1993) describe X-inefficiency as a variance from the efficient frontiers set by the best practice or benchmark firm. It incorporates two components, i.e. technical and allocative inefficiencies (Allen \& Rai, 1996). According to Farrell (1957), technical inefficiency occurs due to sub optimal usage of input leading to waste, while allocative inefficiencies arise from inappropriate mix or composition of inputs using inefficient business process. Both inefficiencies are attributed to employee, management or environment factors. Despite the lack of harmony across all methods, it seems clear that $\mathrm{x}$ efficiency differences are much more important than scale and scope efficiencies in banking. Most of the studies found out that average cost Xinefficiencies are on the order of $20 \%$ higher for virtually all size classes of banks as opposed to scale inefficiencies. Scope inefficiencies are difficult to measure but also appear to account for $5 \%$ or less of costs (Berger and Humphrey, 1994; Berger et. al., 1997). Duality concepts have the best economic foundation for analyzing the efficiency of banks for they are based on economic optimization in reaction to market price and competition. The 
Cost Efficiency of Ethiopian Banks

following sections will discuss cost and profit $\mathrm{x}$-efficiency based on the duality concept.

\subsection{Efficiency Measures/Approaches}

The different methodologies for measuring efficiency can be divided into parametric and non-parametric (Leon, 2014). Data Envelopment Analysis (DEA) is the most common and widely used non-parametric method. DEA differs from a simple efficiency ratio in that it accommodates multiple inputs and outputs and provides significant additional information about where efficiency improvements can be achieved and the magnitude of these potential improvements. Moreover, it accomplishes this without the need to know the relative value of the outputs and inputs that were needed for ratio analysis (Cooper, Seiford and Tone, 2000). Some of the most important advantages of the DEA methodology include the lack of restrictions on the functional form, the different variables and values (e.g., ratios) which may be used. There is possibility of measuring those variables in different units, and the fact that any deviations from the efficiency frontier are noticeable (Thanassoulis 2001). The stochastic frontier model is another variant used to address some of the stated weaknesses of DEA. However, the disagreement on frontier model among researchers at present comes to one focus by preferring the lesser of the evils. The non-parametric studies impose less structure on the frontier but commit the sin of not allowing for random error owing to luck, data problems or other measurement errors. If random error exists, measured efficiency may be confounded with these random deviations from the true efficiency frontier. Therefore, a consensus on which efficiency-measuring frontier is preferable has not yet been achieved (Berger and Humphrey, 1997; Goddard et al. 2001). Therefore, the study's conceptual framework is based on the DEA approach which is justifiable from the most important advantages of the DEA methodology. For instance, it includes the lack of restrictions on the functional form, the flexibility of measuring variables in different units, and the fact that any deviations from the efficiency frontier are noticeable (Thanassoulis, 2001). The stated advantages will provide flexibility to the study to use various inputs which are measured in different units (for instance, those measures in number like branch size, staff etc. and others measured in monetary terms like loans, deposits etc).

EJBE Vol. 6 No. 2/2016 


\section{a. Input-Output Specifications}

DEA models can be either input- or output- oriented according to whether the focus is on input minimization while keeping a given output level or output maximization given levels of the inputs. The theoretical literature is inconclusive as to the best choice among the alternative orientations of measurement (Goddard et al. 2001). However, it is important to note that output- and input- oriented models will assume exactly the same frontier, thus, identifying the same set of efficient banks. The non-tangible nature of bank output and theoretical gap in the banking literature on multi-input-multi-output structure causes confusion in the definition of output measurement. There are two different methods of tackling this problem, i.e. production approach and asset /intermediation approach.

\section{b. Production Approach}

Banks are thought as primarily producing services for account holders. They are considered as firms which employ capital and labor to produce different types of deposit and loan accounts. They perform transactions and process documents for customers, such as loan application, credit reports and payment instruments. Under this approach, outputs are measured by the number of deposit and loan accounts or number of transactions performed on each type of product, while total costs are the operating costs used to produce these products. Banks are viewed as producers of two types of services: deposits of funds and users of funds.

\section{c. Intermediation Approach}

Banks are considered as primarily intermediating funds between savers and investors; they are intermediates of financial services rather than producing loan and deposits account services. Since service flow is not usually available, the flows are typically assumed to be proportional to the stock of financial value in the accounts such as the number of dollars of loans, deposits (Berger and Humphery, 1991). Here, input of funds and their interest cost should be included in the analysis since funds are the main 'raw material' which is transformed in the financial intermediation process. This means, banks give intermediation services through the collection of deposits and other liabilities and the transfer of these funds to interest earning assets (Isik and Hassen, 2002). Deposits are included as third input along with capital and labor. As a result, Operating costs, as well as interest costs, are taken into account in the production process. Both approaches do not capture the dual roles of banks as: 
Cost Efficiency of Ethiopian Banks

a) providing transaction (document processing services) and b) being as financial intermediaries that transfer funds from savers to investors.

But each of the approaches has some advantages. The production approach may be somewhat better for evaluating the efficiencies of branches of banks because branches primarily process customer documents for the institution as a whole and branch managers typically have little influence over bank funding and investment decisions. The intermediation approach may be more appropriate for evaluating entire banks because this approach is inclusive of interest expenses, which often accounts for one half to two third of total cost. Furthermore, the intermediation approach may be superior for evaluating the importance of frontier efficiency to the profitability of the bank since minimization of total costs, not just production costs, is needed to maximize profits.

\subsection{Empirical}

Efficiency can be measured using parametric and non-parametric techniques. The applications of non-parametric techniques exceeds the usage of the parametric ones (Berger and Humphrey,1997). The DEA models are the widely used non-parametric techniques among others. The DEA in banks are estimated using the assumption of both CRS and VRS. However, there is a controversy as to rely on which of the two approaches. Supporters of VRS argue that CRS is only appropriate when all firms are operating at an optimal scale (Fiorentino et al., 2006). Therefore, it might be unrelastic to expect perfection in bank operation all the time. Nevertheless, other studies argue in favor of CRS because the CRS allows the comparison between small and large banks (Miller and Noulas,1997). Studies in banking obtain efficiency score estimates under the input-oriented approach. This is most likely due to the fact that banks output can possibly determined considering the level of its input. For instance, a bank mobilizing deposits can generate more loans. In addition, it's assumed that banks have higher control over inputs rather than outputs There are also some studies that adopt the output-oriented approach (Ataullah and Le, 2006). The input-oriented and output-oriented measures always provide the same value under CRS. There might be variation when they are computed under VRS assumption (Coelli et al., 2005). Therefore, in many instances, the choice of orientation has only a limited influence upon the DUM scores obtained (Coelli et. el, 1999). With regard to the approach used, Berger and Humphrey (1997) argue that the intermediation approach is the one favored in the literature. The production approach is criticized for the difficulties in collecting the detailed transaction flow information required in 
the production approach. As a result, the intermediation approach is the one favored in the literature.

The commonly used inputs in DEA computation are deposits, fixed assets and personnel (Casu and Girardone, 2004). However, some studies use branches (Chen, 2001), loan loss provisions (Drake et al., 2003) and equity (Sturm and Williams, 2004) as additional or alternative inputs. Several studies use two outputs, usually, loans and other earning assets (Casu and Molyneux, 2003). Canhoto and Dermine (2003) use the number of branches as an additional output under the assumption that it represents an additional value for retail customers. Finally, recent studies include non-interest income or off-balancesheet items as additional outputs (Weil, 2004).

Studies in Ethiopia are focused on commonly used efficiency measures like expense management or overhead control etc. ADB (2011) report shows that the traditional method of approaching the efficiency measurement issue of financial firms such as banks is the financial ratio analysis which has some major drawbacks. For instance, Berger (2009) mentioned that ratio analyses do not control for individual bank outputs, input prices, or other exogenous factors facing banks in the way that studies using modern efficiency methodology do, may give misleading results. Therefore, the report recommends for managers of banks and policy maker to search alternative tools (such as DEA) that compensate for the drawbacks in financial ratio analysis (ADB, 2011). A breakthrough in such front was the study of Rao and Lakew (2012) who examined the cost efficiency and ownership structure of commercial banks in Ethiopia using data envelopment analysis (DEA) and Tobit models. The study found that the average cost efficiency of state-owned commercial banks over the period 2000-2009 is 0.69 while that of the private commercial banks is 0.74. The aggregate cost efficiency of Ethiopian commercial banks is found to be 0.73 . In addition, the study found little statistical evidence to conclude that the state-owned commercial banks are less cost efficient than the private commercial banks. Thus, ownership structure has no significant influence on the cost efficiency of commercial banks in Ethiopia. Similarly, Lelissa (2014) explored the efficiency level of Ethiopian Banks for the period 2008-2012 using the DEA model and finds a notable variation among banks in terms of level of efficiency. 


\section{Methodology}

\subsection{Measuring Cost Efficiency}

Cost efficiency gives a measure of how close a bank's cost is to what the best practice bank's cost would be for producing the same output bundle under the same conditions (environment, rule and regulation). It is derived from a cost function in which variable cost depends on the prices of variable inputs, the quantities of variable outputs and any fixed inputs or outputs, environmental factors and random error as well as efficiency. Such cost function may be written as:

$$
C=c(w, y)+\mu_{c}+v_{c}------(1)
$$

Where, $\mathrm{C}$ measures variable costs, $\mathrm{w}$ is the vector of price of variable inputs, $\mathrm{y}$ is the vector of quantities of variable outputs, $\mu_{c}$ denotes inefficiency factor that may raise costs above the best-practice level, and $v_{c}$ denotes the random error that incorporates measurement error and luck that may temporarily give banks high or low costs. The inefficiency factor, $\mu_{c}$, incorporates both allocative inefficiencies (from failing to react optimally to relative prices of inputs, w) and technical inefficiencies (from employing too much of inputs to produce y). To simplify the measurement of efficiency, the inefficiency and random terms $\mu_{c}$ and $v_{c}$ are assumed to be multiplicatively separable from the rest of the cost function, and both sides of equation 1 can be represented in natural logs as follows:

$$
\ln C=\ln f(w, y)+\mu_{c}+v_{c}
$$

Where, $f$ denotes some functional form. The term, $\mu_{c}+v_{c}$ is treated as various $\mathrm{X}$-inefficiency and composite error terms measurement.

We define the cost efficiency of bank 'b' as estimated cost needed to produce bank b's output vector if the bank were as efficienct as the best practice bank in the sample facing the same exogenous variable $(w, y)$ divided by the actual cost of bank $b$, adjusted for random error. That is

$$
\cos t E f f^{b}=\frac{C^{\min }}{C^{b}}=\frac{\exp \left[f\left(w^{b}, y^{b}, z^{b}, v^{b}\right)\right]}{\exp \left[f\left(w^{b}, y^{b}, z^{b}, v^{b}\right)\right]} \frac{\exp \left[\ln u_{c}^{\min }\right]}{\exp \left[\ln u_{c}^{b}\right]}=\frac{u_{c}^{\min }}{u_{c}^{b}}
$$

When $u_{c}^{\min }$ is the minimum $u_{c}^{b}$ across all banks in the sample.

The cost efficiency ratio may be thought of as the proportion of cost or resources that are used efficiently. Cost efficiency ranges over $(0,1)$, and equals one for the best practice firm with in the observed data. 
The efficiency measures are estimated by using non-parametric technique called Data Envelopment Analysis (DEA). The DEA model is a methodology for analysis of the relative efficiency for multiple inputs and outputs by evaluation of all decision-making units (DMUs) (Charnes et. al., 1978). The DEA measures efficiency performance in respect to the best practice banks, which is called efficient frontier. Some of the most important advantages of the DEA methodology, includes the lack of restrictions on the functional form, the different variables and values (e.g., ratios) which may be used, the possibility of measuring those variables in different units, and the fact that any deviations from the efficiency frontier are noticeable (Thanassoulis, 2001). However, it is sensitive to extreme observations and choice of variables as inputs and outputs. The study uses both the CCR and BCC models and their divisional output to compute for the scale effect or scale efficiency. CCR-model was developed by Charnes, Cooper and Rhodes (Charnes et. al. (1978). Its specific assumption is that the DMU operates under constant returns to scale (CRS). BCC-model was defined by Banker et. al., (1984). It estimates the efficiency under the assumption of variable returns to scale (VRS). The basic DEA problem to estimate the relative efficiency of each bank is given by:

$\theta *=$ Min $\theta$ subject to:

$$
\begin{array}{cc}
\sum \lambda j \text { xij } \leq \theta x i o & i=1,2, \ldots . m \\
\sum \lambda j \text { yrj } \geq \text { yro } & r=1,2, \ldots . . s \\
\sum \lambda j=1 & \\
\lambda j \geq 0 & j=1,2, \ldots \ldots . n
\end{array}
$$

Where xio and yro are the i-th input and r-th output of the Bank under evaluation, respectively and $\theta$ is a bank-specific scalar that varies between zero and one and conveys the efficiency score of the specific bank. Banks with $\theta \mathrm{i}=$ 1 their input-output mix lies on the efficient frontier. The $\lambda \mathrm{j}$ is an $\mathrm{Nx} 1$ vector of bank-specific weights that conveys information on the benchmark comparators for bank $i$. A modification of the model with addition of the convexity constraint, $\sum \lambda \mathrm{j}=1$ allows to compute efficiency under variable returns to scale (VRS) and disentangle technical efficiency from scale efficiency. The VRS model thus envelops the data more tightly and provides efficiency scores that are equal or greater than those of the CRS model (Banker et al., 1984).

DEA differs from a simple efficiency ratio in that it accommodates multiple inputs and outputs and provides significant additional information about where 
efficiency improvements can be achieved and the magnitude of these potential improvements. Moreover, it accomplishes this without the need to know the relative value of the outputs and inputs that were needed for ratio analysis (Cooper, Seiford \& Tone, 2000). However, DEA is also subject to few limitations. DEA assumes data to be free of measurement error and that it is sensitive to outliers. Coelli et. al., (2005) also point out that having few observations and many inputs and/or outputs will result in many firms appearing on the DEA frontier. The study uses the DEA to compute the efficiency score of banks and the aggregate industry. The estimated DEA efficiency scores (for both $\mathrm{X}$ and scale efficiency) are then used as regressors in a second-stage model in order to observe the relationship between efficiency and profitability. In addition, the scores are used to test whether there is efficiency variation among private and state-owned banks.

\subsection{Definition of Inputs and outputs using Descriptive Statistics}

The DEA model applies the intermediation approach which relies mainly on the intermediation role of banks but with a consideration of banks activities in non-interest income sources. The description of inputs and outputs is shown below and the rationale of choosing them is described in the following part using descriptive statistics of the variables.

$\begin{array}{lll}\begin{array}{l}\text { Table 1: Inputs and Outputs and their Corresponding Prices } \\ \text { Inputs }\end{array} & \begin{array}{l}\text { Price/input } \\ \text { Prices }\end{array} & \text { Cost of fund } \\ \text { Deposit } & \text { Interest expenses } & \text { Branch running costs } \\ \text { Branch } & \text { Staff expenses and rent } & \text { Fixed asset depletion rate } \\ \text { Fixed assets } & \text { Depreciation, amortization } & \text { Price/output } \\ \text { Outputs } & \text { Prices } & \text { Effective interest rate } \\ \text { Loans and advances } & \text { Interest income } & \text { Earning rate of non- } \\ \text { Other Earning assets } & \text { Non-interest income } & \text { interest income sources }\end{array}$

\section{Source: Author's}

The study applies the intermediation approach which is appropriate for evaluating the entire banks through incorporating inputs from core operation of banks. In addition, its suitability for evaluating the importance of frontier efficiency to the profitability of the bank is believed to provide added value during the test of the efficiency-performance relationship in Ethiopian banking industry. The intermediation approach is also more appropriate for evaluating entire banks because this approach is inclusive of interest expenses which often 
Cost Efficiency of Ethiopian Banks

accounts for one half to two third of total cost. Besides, the intermediation approach is superior for evaluating the importance of frontier efficiency to the profitability of the bank since minimization of total costs, not just production costs, is needed to maximize profits. Therefore, the DEA intermediation approach is used: to explore the level of efficiency in the Ethiopian Banking System as well as to examine if there is any variation in efficiency among Ethiopian banks.

\subsection{Data Sources and sampling}

The study uses firm level (mainly commercial banks) as well as aggregate data of the industry basically the coverage is from 1999-2015. The major data sources are the various annual and quarterly publications and financial accounts of NBE and commercial banks consisting of all 18 commercial banks in Ethiopia.

\section{Testing the Efficiency Variation and its Determinants}

Descriptive statistics on the input side shows that the average industry deposit stood at Birr 8,809.8 billion which is far lower as compared to the maximum deposit raised by the giant bank, the Commercial Bank of Ethiopia, Birr 241,732 billion. The distribution witnessed that there is a concentrated distribution in terms of resource mobilization towards the state-owned banks. This can be easily observed if one considers the dominance in the market share of deposit by the big commercial bank. Literally, the entry of private banks seems to have marginal effect on reducing the market share of the state bank. In terms of market share, therefore, the commercial bank of Ethiopia and the two state banks together accounted for $65 \%$ and $68 \%$ of the industry's deposit market share, respectively. The remaining 32\% share is divided up among private banks which are significant in number as compared to the state owned banks. Of the private banks' market share, the recent entrant banks have a slight share of the market and dominance from middle level private banks remained the norm.

On the other front, the average branch size per bank is 75 over the 17 years period under consideration. Therefore, on average a bank in Ethiopia is operating opening 75 branches which is indicative of the dominance of a brick and mortar approach where proximity through physical presence remained the banking mode preferred by the Ethiopian banks. There is however an instance where a bank has opted to operate with a single branch model supported by 
multichannel banking system. Nevertheless, such approach seems doesn't get acceptance from the regulatory side in consideration of the policy framework to ensure financial inclusion through increasing bank branches. Therefore, banks are required to increase their branch size (in number) by $25 \%$ per annum so that they can support the government stance towards creating access to finance to the poor through establishing bank premises all over the country. Therefore, incorporating branch size as an input remains relevant to this study taking in to account that banks are investing and are expected to invest a big sum of their capital to establish a large network of branches. This is done not only due to the banks' choice of branch as a growth driver but a strategy need to be pursued to fulfill regulatory requirement. In addition, the choice of branch opening is subjected to approval from the regulatory side and is not under the discretion of the Banks. In addition to the dominance of a large branch network, banks are also investing a lot in the acquisition of both tangible and intangible fixed assets. Investments on premises, vehicles and Information technology takes the major share of the Banks investment in fixed assets. On average, a bank invested Birr 135 million in fixed asset acquisition which remained large in consideration of a Birr 75 million entry capital during the past which is now grown to Birr 500 million and expected to reach Birr 2 billion under the Growth and Transformation Plan II (GTP II) of the country. Therefore, with the growth in capital entry to the sector will remain restricted and the existing banks will be directed towards investing their capital on asset acquisition like owning head office and branch buildings, automations and introduction of e-banking products. Hence, the management of such investment which will have a direct impact on efficiency through affecting associated costs like depreciation and amortization expenses, IT license fees and fixed asset management. It's therefore essential to observe the effect of banks decision on fixed asset acquisition on their efficiency through incorporating fixed asset investment on the input side. 
Cost Efficiency of Ethiopian Banks

Table 2: Descriptive Statistics of Inputs and Outputs

\begin{tabular}{|l|l|l|l|l|l|}
\hline Variable & Obs & Mean & Std. Dev. & Min & Max \\
\hline Deposit & 193 & 8809.762 & 26974.54 & 37 & 241732 \\
\hline Branch & 193 & 75.74093 & 129.6661 & 1 & 977 \\
\hline Fixed asset & 193 & 135.5803 & 241.6888 & 3 & 1740 \\
\hline Loans & 193 & 4568.306 & 12516.1 & 37 & 111435 \\
\hline Earning Asset & 193 & 4661.383 & 17914.83 & 6 & 158730 \\
\hline Interest expense & 193 & 177.4974 & 479.6913 & 0 & 4749 \\
\hline Staff expense & 193 & 112.5285 & 305.858 & 1 & 3038 \\
\hline General expense & 193 & 103.715 & 227.3732 & 2 & 2339 \\
\hline Interest income & 193 & 527.0326 & 1646.089 & 1 & 15269.3 \\
\hline Noninterest income & 193 & 324.9171 & 816.9076 & 0 & 6837 \\
\hline
\end{tabular}

\section{Author's Computation (STATA 12)}

On the output side, the banking system main channel of earnings are related to intermediation and fee income collected through exposure from earning assets mainly of earning from foreign transactions. On the intermediation front, banks credit activities takes the lead with an average loan to deposit exposure of $56 \%$ which proves that the Ethiopian banks are highly reliant on the intermediation business for their earnings. The concentration observed in the deposit market is also similar but at a reduced level is witnessed in the credit business. The market share of the CBE reach $60 \%$ of the total credit extension and the reimaging share belongs to the private banks. The average outstanding loan, Birr 4 billion of the system, is also far less than the credit exposure of the big bank, Birr 111 billion which is a further indication of the dominance of the state bank in this market.

The other component of output earning from other assets mainly composed of bank's foreign currency deposit in foreign correspondent banks remained a determinant factor for fee income collection through financing import activities. In addition, the earning asset constitutes a policy measure from the regulator for banks to purchase a certain portion of their deposit to purchase the government bills. This is attached with loan disbursement where banks are expected to spend around $27 \%$ new loan disbursement in the form of bill. This is attached with a $3 \%$ interest rate which is lower from the $5 \%$ minimum deposit rate required to be paid for saving and fixed time deposit holders. One of the important policy discriminations is that the exclusion of the big stateowned bank from such obligation despite the expectation for all private banks to comply with the prerequisite. Such policy requirement obviously will have 
impact on efficiency of banks through placing a certain portion of their resources on low earning investments. In terms of amount, the earning assets eluding loans on average is Birr 4.6 billion which is almost equivalent of the level of the lending business. Therefore, despite the large share of the intermediation, business banks seem to engage in fee income activities to boost their earning level. Considering such output, therefore, will have crucial importance as the intermediation business in consideration of the significant share in the balance sheet and its high contribution to earnings in the form of non-interest income.

The input price which has a direct association with the selected inputs is also one of the determinant factors of efficiency in banking operation. For instance, bank's liquidity mainly built through collecting local and foreign resources in the form of customer deposits shows that banks on average are paying more than Birr 170 million per annum over the last 17 years for the resources mobilized. This will create an effective cost fund of 3\%, which seems lower than the 5\% minimum deposit rate to be paid for saving and fixed time deposit mainly due to the relatively good share of low cost deposit types like demand deposits. The staff expenses and general expenses which are applied as a running cost for branches and some head office businesses like bank promotion, fixed asset management and others also take a significant portion of banks expenses. The average amount of expenses on staff salary and general expenses are almost equivalent to the price paid to deposits. Therefore, management's capacity to control the level of expenses will be one of the determinant factors besides banks' capacity to build their liquidity through creating a reliable and cost-effective deposit mixes.

Building the earning base of banks through extending quality loans and reducing the level of inefficiency arising from non-performing assets is also another determinant factor of bank efficiency. The average interest income of the banking group over the 17 years is Birr 527 million per annum, with a denominator of an average of Birr 4 billion loans. This yields an effective interest rate from loans of $12 \%$. Attached with $3 \%$ cost of fund, the banking industry remained enjoying a wider spread of $9 \%$. The income from fees and commissions which is mainly derived from the non-intermediation business has a bit wider gap as compared to the income obtained from intermediation business. Therefore, considering the restrictive policies on the lending side, it seems there is still a room towards boosting the share of the non-intermediation businesses. The average non-interest income of the banking sector over the last 
Cost Efficiency of Ethiopian Banks

17 years is Birr 324 million per annum which is less as compared to Birr 527 million income from loan interest income.

\subsection{The DEA Efficiency Scores Results}

The average cost efficiency of the Ethiopian banks under the constant return scale approach is $84 \%$ which is indicative of the fact that some of the banks in the group could have earned more through using the same level of inputs. Or else, the output level they have generated so far could have been produced through a reduced level of input usage. The other scenario that could be observed is that there is a wider variation among banks in terms of their efficiency level. For instance, the minimum cost efficiency level of some banks is reduced to $27 \%$ which is mostly related to new entrant banks as it takes time for their investments in fixed assets and branch usage to produce the expected results. Therefore, with the exclusion of the freshness effect, the minimum efficiency score will grow to $68 \%$. This will show a better picture than what has been reported but will not change the fact that there is a divergence in efficiency level across banks. A rather improved picture has been revealed on the variable return scales approach where banks average efficiency level has grown to $92 \%$. Nevertheless, the variation factor which is not affected by entry time is still prevalent with a deviation from the minimum and maximum efficiency score stood at $36 \%$. Therefore, despite the good average record of efficiency noted on aggregate, the variation observed points that there are banks in the sector that need to bring their efficiency level at the industry level. The scale effect, which is a quotient from the constant and variable return scale, signal an improved efficiency status than the efficiency level under constant return scale but with an indicative point on remaining tasks towards more improvement.

Table 3: Descriptive Statistics of Efficiency Scores

\begin{tabular}{|l|l|l|l|l|l|}
\hline Variable & Obs & Mean & Std. Dev. & Min & Max \\
\hline Cost Efficiency (CRS) & 193 & .8420893 & .1255129 & .271874 & 1 \\
\hline Cost Efficiency (VRS) & 193 & .9236762 & .0930616 & .6415 & 1 \\
\hline Scale Cost Efficiency & 193 & .9142754 & .1138639 & .271874 & 1 \\
\hline Profit Efficiency (CRS) & 193 & .8317337 & .2072173 & .21752 & 1 \\
\hline Profit Efficiency (VRS) & 193 & .8987414 & .1686922 & .31642 & 1 \\
\hline Scale Profit Efficiency & 193 & .9253778 & .1407859 & .21752 & 1 \\
\hline Revenue Efficiency (CRS) & 193 & .868658 & .1254732 & .508995 & 1 \\
\hline Revenue Efficiency (VRS) & 193 & .9144616 & .1070092 & .616366 & 1 \\
\hline Scale Revenue Efficiency & 193 & .9508949 & .0847197 & .508995 & 1 \\
\hline
\end{tabular}

\section{Source: Author's Computation}

EJBE Vol. 6 No. 2/2016 
Cost Efficiency of Ethiopian Banks

A rather improvement is portrayed if one considers the revenue efficiency level of Ethiopian banks. The revenue side performances under constant return scale marginally step up to reach $87 \%$. Therefore, despite the notable effect of a variation on cost control, the revenue generating capacity of banks was on high front. This is as a result of the wide spread banks were enjoying from their intermediation activities along with the relatively high commission rate on forex business taking advantage of the scarce availability of such resources in the industry. Banks take the upper hand on channeling and deciding the amount of pricing of such resources. This has resulted in a relaxed cost control affecting the level of profit efficiency to some extent. A further look at on the profit efficiency level shows a rather reduced performance where the average efficiency score for banks stood a bit lower than the cost and efficiency levels. Therefore, the effect arising from a relaxed cost control seems outweighing the positive effect derived from high margins ultimately impacting the level of the profit efficiency to the negative. Such assessment could be further clarified considering trend factors and individual bank performance as shown in the next section.

\subsubsection{Cost Efficiency and Trends under CRS and VRS Models}

This section of the study investigates whether there has been an improvement and convergence of cost efficiency in the Ethiopian banking markets since the introduction of the private banking system. This is done applying efficiency measures derived from DEA estimation. The overall DEA results show relatively low average efficiency levels, $84 \%$ with an efficiency level ranging from $75 \%$ to $91 \%$. Nevertheless, trend wise, it is possible to distinguish a slight advance in the average efficiency scores over the period of analysis for almost all banks in the sample. However, the results show that the efficiency gap among banks relatively grew even wider over the period 1997-2015. A more diverging trend has been noted when one considers the gap in efficiency among the state owned bank and private banks. Surprisingly and unlike the expectation on a reduced efficiency from state owned banks, the performance of the big bank has been consistently on the top of the frontier. The expectation of a reduced state ownership is due to their high involvement in some political decisions like financing of government priority sectors like agriculture, export, industry etc. and a demand from the government to serve the under developed banking market through operating a wider branch network. Nevertheless, the results appear unique and state ownership established a secular relationship with efficiency. The reduced trend in efficiency score of state banks in aggregate is a result of the poor performance

EJBE Vol. 6 No. 2/2016

Page 142 
from the Construction and Business Bank which recently decided to be merged with the big state-owned bank. Therefore, the introduction of a private banking system doesn't alter or even has improved the efficiency performance of the state-owned bank unlike the expectation for its reduction due to a gradual take over in market share from private banks. Another important finding is that the efficiency score of private banks is characterized by a fluctuation trend with an improvement in recent period but a down drop curve during 2015. The entry of new private banks seems affecting mostly of the existing private banks than the giant state bank. Therefore, if one expects any sign of competition due to entry of banks in the market that will be a competition arising from private banks themselves rather than among state and private owned banks.

Figure 1: Cost Efficiency of Ethiopian banks from 1999-2015

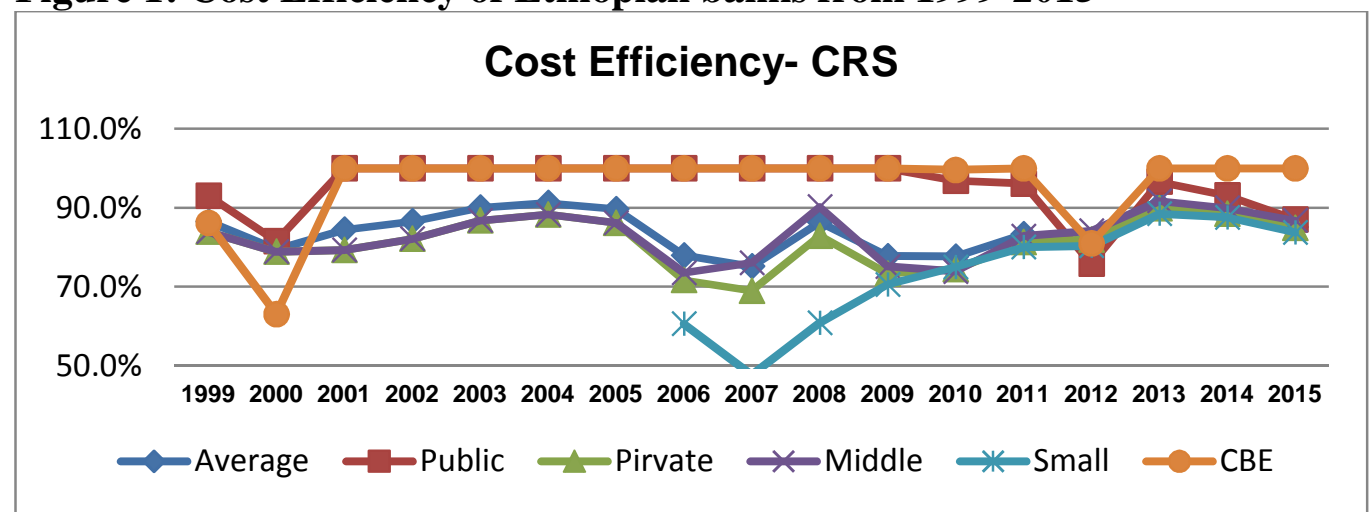

\section{Source: Author's Computation}

Additional observation on efficiency of banks after entry of small banks after year 2006 shows that the small banks relatively took a long period to adjust and approach the efficiency level of already operating banks. Currently however a good level of efficiency gain is arising from the small private banks whose efficiency trend is coming closer to the middle level private banks but the score still remains lower as compared to the big state-owned bank and the middle level private banks. Individual basis analysis shows that there are some private banks under the middle-income group which are periodically losing their efficiency level unlike a good performance from small banks which managed to bring their efficiency score towards the frontier. Therefore, the $\mathrm{x}$ inefficiency from the middle bank group is on the rising trend with a high variation observed across banks. This is because the high growth rate in private banks seems challenged to attract better management of inputs costs which should remain a cause of concern attracting the attention of the banks 
management and the regulatory policy interventions. In terms of number of efficient Decision making Units (DMUs), despite the growth in the number of banks over the years, the number of efficient DMUs remained constant with average number of efficient DMUs not exceeding two. Therefore, the effort to bring the banks in the frontier remains a duty waiting the participation of most banks in the industry. In terms of the efficiency gap, the gap between the efficiency score of private banks and the CBE is on average 15 percentage points with a maximum difference of 31 percentage points in year 2007 which is substantial and remained strongly divergent.

\subsubsection{Cost Efficiency -Variable Returns to Scale}

The estimation result from the VRS model depicts a more plausible performance in the number of efficient banks and the average efficiency for the sector as compared to the result from the CRS model, implying that the main source of inefficiency is due to scale inefficiencies. The average efficiency score under the VRS model shows an eight percentage point improvement to reach to $92 \%$. Even with such level, there is a still a room for an efficiency improvement through improving the input usage and control of their associated costs. In terms of efficient DMUs the picture shows improvement of the 18 banks 5 of them pick up towards the frontier which is double from the efficient DMUs record of the CRS output. Nevertheless, the proportion of efficient DMUs decreased over time and the average efficiency shows a variation with a decrease in trend during the recent periods although the drop is less substantial than in the CRS case. The standard deviation shows a similar pattern and stateowned banks appear to be more efficient than private banks in terms of average efficiency scores dominating the frontier. Surprisingly, the CBE score under all the periods considered is on the frontier resulting in similar unexpected result from the theoretical expectation of a low efficient score. Unlike the CRS model under the variable scale, the small private banks registered a high efficiency score exceeding the level observed on middle size private banks score. Therefore, the result shows that most of the small banks are operating under an increasing return scale and the effect of size diminishes overtime unless exceptionally large difference in size is observed across banking groups. The efficiency score output by size, therefore, shows that the source of $\mathrm{x}$ inefficiencies are mostly felt on middle size banks which are expected to improve their management capacity in line with the growth of their businesses. The deviation among banks also remained wide but portrayed a narrow picture as compared to the CRS model. One of the worrying issues revealed in both models is the recent period performance in efficiency for private banks is on 
Cost Efficiency of Ethiopian Banks

the downward trend despite a strong picture for the large state-owned bank. This is in association with the restricted intermediation activity following a change in policy towards engaging the private banks on purchase of bills. This obviously impact the level of intermediation as well as the income obtained thereof through exposing part of the banks' asset on low earning placements. Similarly, the average state-owned efficiency is on the downward trend due to the decrease in performance of the other state-owned bank in the group. Nevertheless, the big state-owned bank, which is exempted from bill purchase, remained on top of the efficiency score enjoying non-compliance to the lending restrictions.

In summary, it appears that during the recent period, there was no improvement in efficiency in the banking sector in Ethiopia and no convergence in the sector is apparent. State owned banks consistently record higher efficiency scores and the gap between state and private banks seems large and with modest increase. The result suggests that the largest state-owned bank is more efficient than the private banks. However, the performance of the small ones is improving to exceed early entrant middle size private banks especially the differences are substantial in the VRS model. Thus, the main source of inefficiency is partly due to scale inefficiencies stemming from large banks but management inefficiencies could also be cited considering a better growing efficiency of small banks as compared to the efficiency growth of middle private banks.

Figure 2: Cost Efficiency of Ethiopian banks under VRS from 1999-2015

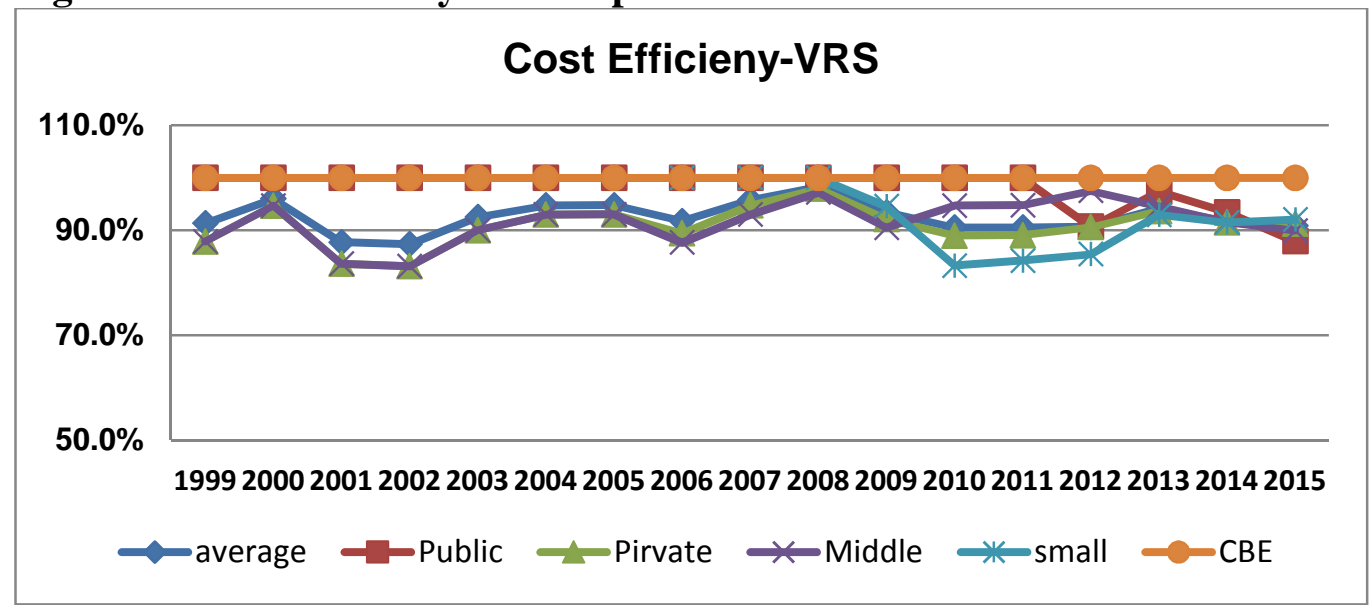

Source: Author's Computation

EJBE Vol. 6 No. 2/2016 
Cost Efficiency of Ethiopian Banks

\subsubsection{Scale Efficiency}

The results for the pooled model in general confirmed the earlier findings that scale inefficiency is the dominant factor in influencing the efficiency of banks. The analysis based on VRS shows that small banks exhibited a higher mean pure cost efficiency of 92.4 percent compared to middle sized private banks (91.6 percent). This suggests that small banks are managerially efficient in controlling costs compared to their middle size counterparts and are operating under increasing returns to scale. However, due to the effect of the CRS output, the mean scale efficiency of small private banks remained lower than both private middle banks and state-owned banks. The result for state owned banks remained the same with an average score on the frontier in most years of the period considered with the efficiency scale on the frontier for the CBE in all cases. It is interesting to note that the degree of cost efficiency under CRS for private banks is lower than the degree of scale efficiency which indicates that a portion of overall inefficiency is due to producing below the production frontier rather than producing on an inefficient scale. Nevertheless, most of the cost inefficiency exhibited by the banks stem from operating at the wrong scale; ether operating at a scale that was too large (DRS) or operating at a scale that was too small (IRS). Since the major source of inefficiency in the Ethiopian commercial banking system is scale inefficiency, this study then examines further the trend in the returns to scale of Ethiopian commercial banks as shown in the following section.

Figure 3: Cost Efficiency of Ethiopian Banks 1999-2015 Scale Effect

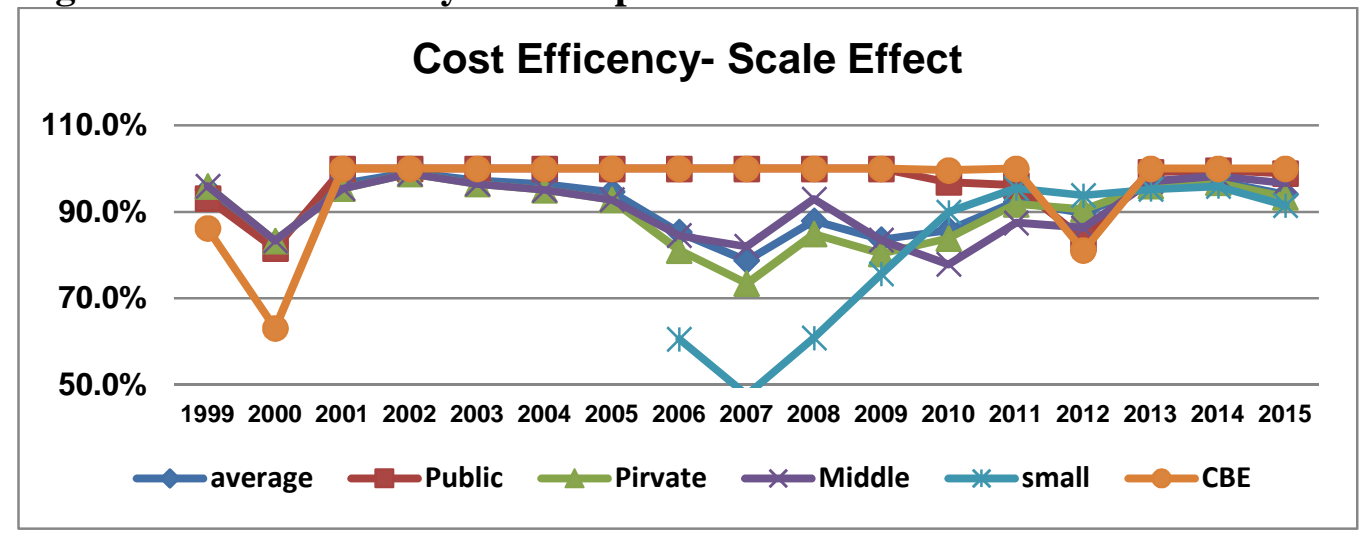

Source: Author's Computation

EJBE Vol. 6 No. 2/2016 
Cost Efficiency of Ethiopian Banks

\subsection{Developments in Returns to Scale (RTS)}

DEA provides information about scale efficiency as the ratio of the constant return scale efficiency score to the variable return scale efficiency score to identify whether the efficiency score of a given observation is not influenced by moving from a constant returns to scale operation to a variable returns to scale operation. As shown above, the results for the Ethiopian banking system indicate high levels of scale efficiency with notable variation from year to year. Nevertheless, with regard to the direction of scale inefficiency, it appears a common phenomenon among the private banking system to operate under too high scale (decreasing returns to scale) or too low scale (increasing returns to scale). In contrast, the share of scale efficient (constant return to scale) in private banks is small and remained less than $10 \%$ in the period considered. On aggregate basis, the results for the private banking system favor an increasing return to scale operating region. However, further breakdown of the data by size of private banks shows that the number of private banks experiencing economies of scale (IRS) mostly favors smaller than the middle size private banks. The middle level private banks were experiencing diseconomies of scale (DRS) with a decline in the number of banks operating under increasing or constant return to scale. On the other front, the distribution of returns of scale suggests that the state banks are mostly operating under constant return scale. The experience in managing inputs and controlling associated costs seem strong in the stated owned banks on account of their long time stay in the industry. A historical trend skewed towards optimum scale operation along with an efficiency score consistently on the frontier shows that such banks are managing their costs and operations efficiently. On aggregate basis, the result for all years (pooled) suggest that the share of banks experiencing economies of scale, diseconomies of scale and scale efficient is $37 \%, 45 \%$ and $18 \%$, respectively, all witnessing that scale problems are pronounced in the Ethiopian banking system. In other words, the results suggest that the share of scale efficient banks (CRS) was small. Therefore, a majority of the small private banks seem to increase the scale of operation in order to achieve the optimal scale and vise-versa for the middle size private banks (Table 6).

\subsection{Parametric and Non-Parametric Tests}

After examining both the efficiency scores and sources of inefficiencies, we investigate further whether each group of bank, private and state banks are drawn from the same population and whether these two groups possess the 
same management or technology capability. The hypothesis to be tested is framed as follows:

$\mathrm{H} 0=$ state banks and private banks are drawn from the same environment or technology $\mathrm{H} 1=$ state banks and private banks are drawn from a different environment or technology.

Table 4: Test on Efficiency Variation across Banks

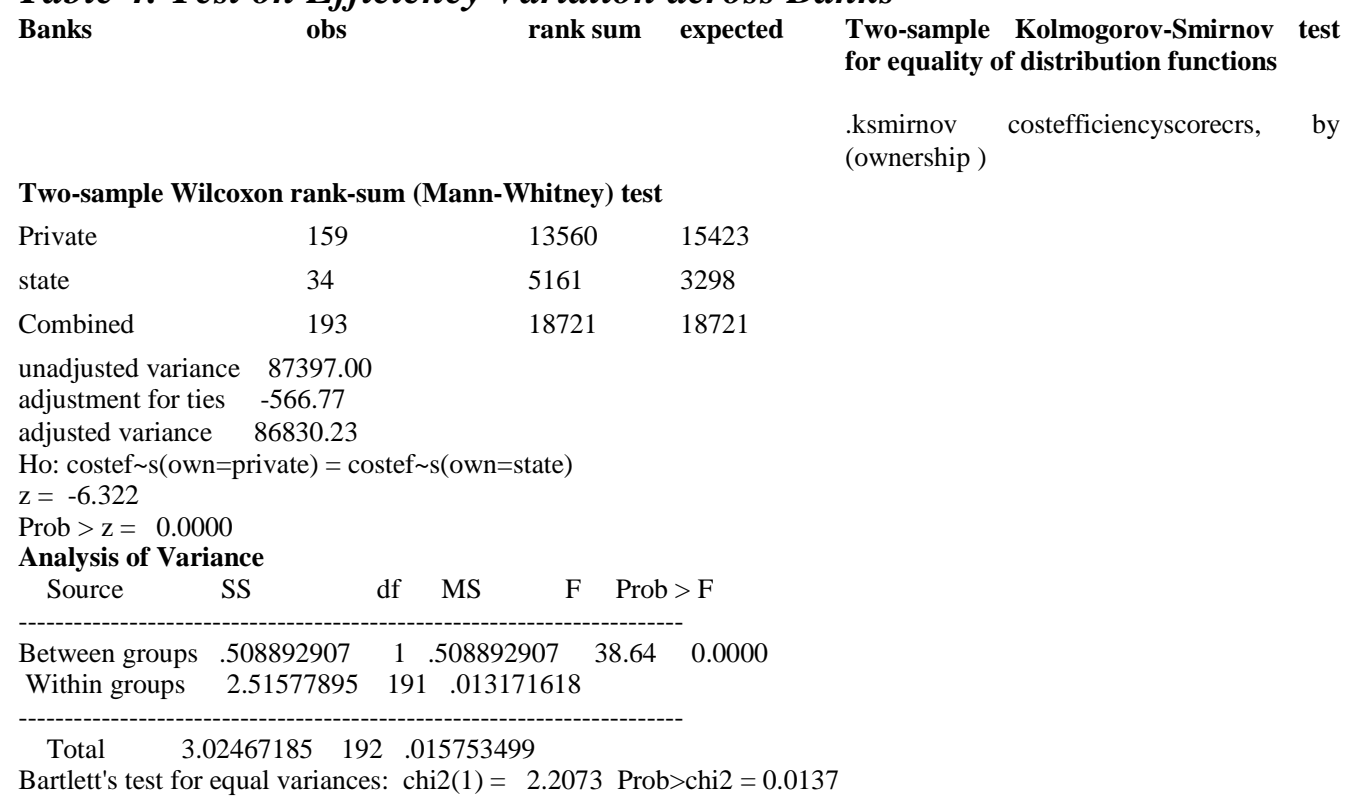

\section{Source: Author's Computation}

Both parametric (analysis of variance and t-test) and non-parametric (Wilcoxon Rank-Sum and Kolgomorov -Smirnov) tests are used to test the null hypothesis that the two groups are drawn from the same population and have identical management/technologies. From the results, we reject the null hypothesis that the state and the private banks have similar management and technology capabilities. This suggests that banks observed have access to different management capabilities and more efficient technology. Therefore, we can conclude that, it is appropriate to separate the samples because these two groups of banks, private and state banks, have different management/technologies causing a variation in their efficiencies. The efficiency scores from the analysis clearly indicate that, public banks appear more efficient with the highest efficient level as close to 1 in all the years by both the models. It is clearly shown that Ethiopian banking sector is still 
Cost Efficiency of Ethiopian Banks

dominated by public banks which are possessing efficient technologies and management capabilities.

\subsection{Benchmarking, Slack and Improvements}

The table below illustrates the areas of improvements in year 2015 for banks. The purpose of such assessment is intended to set example to banks on the use of the DEA output for benchmarking and improvements. In addition, the study explores whether the benchmarking result is coherent with the return to scale difference observed in the banking system. As shown in the table, some banks need a lot of adjustments to achieve efficiency. For instance, some banks needs to decrease total deposits and/or else increase branch sizes. From the output side, increase in lending and earning assets could also improve performances of banks (see annex for output benchmarking). The above analysis is consistent with the previous section findings related to return to scale. Some banks are affecting their return of scale due to excessive holding of liquid assets and engaging in more aggressive branch expansion. This is limiting the efficiency of banks by holding large some of unproductive resources and costing banks in terms of excessive branch running costs. On the output side also bank loans and earning assets are not expanded as compared to their resource holdings. This obviously affects their efficiency levels (Table 7).

\subsection{Determinants of Efficiency}

After looking at efficiency as an important determinant factor of performances, we have moved the quantitative analysis to explore which of the inputs and outputs variable are the determinant factors of efficiency. The description and variables are shown in the DEA analysis above. The statistical test shows that deposit growth rate, loan size and earning asset growth are positively and significantly related to efficiencies. Nevertheless, branch size and fixed asset growth rate are negatively and insignificantly related to efficiencies. 
Cost Efficiency of Ethiopian Banks

$\begin{array}{lll}\text { Table 5: Empirical Results on Efficiency Determinants } & \\ & \text { Model 1 } & \text { Model 2 } \\ & \text { XEFF } & \text { SEFF } \\ \text { Deposit Growth Rate } & .4233 & .1423 \\ & (0.0000)^{*} & (0.0000)^{*} \\ \text { Log (Loan size) } & 0.5862 & .4652 \\ & (0.0005) & (0.0000)^{*} \\ \text { Earning Asset Growth } & 0.8121 & .5623 \\ & (0.0000)^{*} & (0.0000)^{*} \\ \text { Branch size(number) } & -.31552 & -.3486 \\ & (0.4210) & (0.5210) \\ \text { Fixed Asset Growth } & -. .43560 & -.3486 \\ & (0.3256) & (0.5200) \\ \text { CONS } & 10 . .3744 & 12.13794 \\ & (0.0000)^{*} & (0.0000)^{*} \\ \text { Adjusted R2 } & 46.32 \% & 36.25 \% \\ \text { Walid Chi2 } & 176.8 & 146.52 \\ & (0.0000)^{*} & (0.0000)^{*} \\ \text { F-test } & 53.4 & 65.2 \\ & (0.0000)^{*} & (0.0000)^{*} \\ \text { LM test } & 128.6 & 114.5 \\ \text { Hausman Chi2 } & (0.0000)^{*} & (0.0000 * \\ & 5.6 & 6.2 \\ & (0.8546) & (0.7869)\end{array}$

\section{Source: Author's Computation}

\subsubsection{Summary and Conclusions}

This part of the study has explored the efficiency level of banks using cost models. It has used the Data Envelopment Analysis score to examine the efficiency level of banks under both constant and return of scale. In addition, it has explored the scale efficiency of all the models. The study finds that banks efficiency level has witnessed a wide variation across various bank groupings. The study has also found that the state banks efficiency has been consistently on the efficiency frontier reflecting the high dominance of the banks in the Ethiopian banking system. In addition, the study finds that the small private banks efficiency is growing overtime while the middle size private banks are facing difficult to improve their level of efficiency. The parametric and nonparametric tests also witness that state and private banks possess different management and technology capabilities. This shows that despite the scale 
advantage the state banks have, the difference in their management and technology capabilities has contributed for better efficiency performances. On the other front, the result from the DEA score shows that the efficiency score of the state-owned banks has been consistently on the top of the frontier while using both the Constant Return to Scale (CRS) and Variable Return to Scale (VRS). This remains to be an unexpected result in consideration of the anticipation for state banks' inefficiency which is the main government policy maneuvers. For instance, government action to enforce state owned banks to finance priority sectors at lower price is expected to affect their efficiencies via reducing their earning from intermediation. On the other front, the efficiency score for state banks remained strong even during the times when more private banks were entering in the sector. This suggests that the introduction of a private banking system doesn't alter the efficiency performance of the stateowned bank unlike the expectation for its reduction due to a gradual takeover of its market share by the private banks. There is, however, a mixed result in the efficiency scales among the private middle and small banks under CRS and VRS. The small size private banks, whose efficiency trend is coming closer to the middle level private banks, has a lower efficiency score as compared to the state-owned banks and the middle level private banks under CRS. Nevertheless, unlike the CRS model, the small private banks registered a high efficiency score exceeding the level observed on middle size private banks' score under the VRS. The mixed result shows that most of the small banks are operating under an increasing return scale and the effect of size diminishes overtime. The efficiency score output by size, therefore, shows that the source of $x$-inefficiencies are mostly felt on middle size banks which are expected to improve their management capacity in line with the growth of their businesses. Another important finding is that the efficiency score of private banks is characterized by a fluctuation trend with a down drop curve in recent period. The entry of new private banks seems to affect more the existing private banks than the giant state bank. Therefore, if one expects any sign of competition due to entry of banks in the market that will be a competition arising from private banks themselves rather than among state and private owned banks. The test for efficiency variation through both parametric and non-parametric tests, therefore, confirms that there is widely noted efficiency variation among banks operating in the country. For instance, in terms of the efficiency gap, the gap between the efficiency score of private banks and the CBE is on average 15 percentage points with a maximum difference of 31 percentage points in year 2007 which is substantial and remained strongly divergent. In summary, it appears that during the recent period, there was no improvement in the efficiency in the banking sector in Ethiopia and no convergence in the sector is 


\section{Cost Efficiency of Ethiopian Banks}

apparent. State owned banks consistently record higher efficiency scores and the gap between state and private banks seems large and with modest increase. The result suggests that the largest state-owned bank is more efficient than the private banks. However, the performance of the small banks is improving to exceed early entrant middle size private banks especially the differences are substantial in the VRS model. Thus, the main source of inefficiency is partly due to scale inefficiencies stemming from large banks but management inefficiencies could also be cited considering a growing efficiency score of small banks as compared to the efficiency score growth of middle private banks. The overall DEA results under CRS show relatively low average efficiency levels, $84 \%$ with an efficiency level ranging from $75 \%$ to $91 \%$. The average efficiency score under the VRS model shows an eight percentage point improvement to reach to $92 \%$. Even with such level, there is still a room for an efficiency improvement through improving the input usage and control of their associated costs. In addition, public banks are more efficient with the highest efficient level as close to 1 in all the years by both the models. It is clearly shown that the Ethiopian banking market is still dominated by the public bank. 


\section{References}

Adongo, J., Christoph, S. and Elisa,H. (2005). Measuring the Alternative Profit X-efficiency of Namibia's Banking Sector. The Namibian Economic Policy Research Unit. (Research Report No. 36.)

Allen, L. and Rai, A. (1996). Operational efficiency in banking: an international comparison, Journal of Banking and Finance, Vol. 20, pp. 655-72.

Banker, R., Charnes, A. and Cooper, W. (1984). Some models for estimating technical and scale inefficiencies in data envelopment analysis, Management Science, Vol. 30 No. 9, pp. 1078-92.

Berger, A. and Humphrey, D. (1994). Bank scale economies, mergers, concentration, and efficiency: The US experience. Working Paper 9425, Financial Institutions Centre, The Wharton School, University of Pennsylvania.

Berger, A. and Humphrey, D. (1994). Bank scale economies, mergers, concentration, and efficiency: The US experience. Working Paper 9425, Financial Institutions Centre, The Wharton School, University of Pennsylvania.

Berger, A., and Humphrey, D., (1997). Efficiency of financial institutions, international survey and directions for future research, European Journal of Operational Research, Vol. 98, pp. 175-212.

Berger, A., Hancock, D. and Humphrey, B. (1993). Bank Efficiency derived from the Profit Function, Journal of Banking and Finance 17, pp.317347.

Casu, B. and Molyneux, P. (2003). A comparative study of efficiency in European banking, Applied Economics, Vol. 35, pp. 1865-76.

Casu, B., Cirardone, C. and Molyneus, P. (2004). Productivity change in European banking: a comparison of parametric and non-parametric approaches, Journal of Banking and Finance, Vol. 28 No. 10, pp. 252140.

Charnes, A., Cooper, W. and Rhodes, E.(1978). Measuring the Efficiency of Decision Making Units. European Journal of Operations Research 6, pp.429-44.

Chen.H , Chuo.Y , Chang.J and Yu.S.(2016) Does Banking Competition Improve Industry Performance? Evidence from Taiwan, Journal of Informatics and Data Mining, Vol. 1 No. 3:16

Coelli, T., Rao, D., and Battese, G.(1998). An Introduction to Efficiency and Productivity Analysis, Norwell, MA: Kluwer Academic Publishers.

Coelli, T., Rao, D.,O'Donnell, C. and Battese, G. (2005). An Introduction to Efficiency and Productivity Analysis, Springer, New York. 


\section{Cost Efficiency of Ethiopian Banks}

Cooper, W., Seiford, L. and Tone, K. (2000). Data Envelopment Analysis: A Comprehensive Text with Models, Applications, References and DEASolver Software, Kluwer Academic Publishers, Boston, MA.

Cooper, W., Seiford, L. and Tone, K. (2000). Data Envelopment Analysis: A Comprehensive Text with Models, Applications, References and DEASolver Software, Kluwer Academic Publishers, Boston, MA.

Debreu, G. (1951). The coefficient of resource utilization, Econometrica, Vol. 19 No. 3, pp. 273-92.

Farrell, M. (1957). The Measurement of Production Efficiency, Journal of Royal Statistical Society, 120, pp. 253-81.

Goddard, J., Molyneux, P. and Wilson, J. (2001). European Banking. Efficiency, Technology and Growth, John Wiley and Sons, England.

Green, J. and Scotchmer, S. (1995). On the Division of Profit in Sequential Innovation, Rand Journal of Economics 26, pp.20-33.

Isik, I. and Hassan, M. (2002). Technical, scale and allocative efficiencies of Turkish banking industry, Journal of Banking and Finance, Vol. 26 No. 4, pp. 719-66.

Kumbhakar, S. and Lovell, C. (2000). Stochastic Frontier Analysis, Cambridge University Press, Cambridge.

L'eon (2014). Measuring competition in banking: A critical review of methods: Etudes et Documents no 12, CERDI.

Leibenstein, H. (1966). Allocative efficiency versus X-efficiency, American Economic Review Vol. 56, pp. 392-415.

Lelissa, T.(2014), Efficiency of Ethiopian Banks: the Data Envelopment Analysis, European Journal of Business and Management, pp.30-36.

Lera D. and Rao. P. (2016). Market Structure, Efficiency, and Performance of the Ethiopian Banking Sector; India Journal of Research, Volume: 5, Issue: 1, January 2016

Thanassoulis, E. (2001). Introduction to the Theory and Application of Data Envelopment Analysis, A Foundation Text with Integrated Software, Kluwer Academic Publishers, Boston,MA. 
Cost Efficiency of Ethiopian Banks

Table 6: Developments in Returns to Scale (RTS) in Ethiopian Commercial Banks

\begin{tabular}{|c|c|c|c|c|c|c|c|c|c|}
\hline Year & Bank Group & IRS & & DRS & $\%$ & Constant & $\%$ & TOTAL & \\
\hline & & $\mathrm{NO}$ & $\%$ & NO & $\%$ & NO & $\%$ & NO & $\%$ \\
\hline \multirow[t]{3}{*}{1999} & State & 0 & $0.0 \%$ & 1 & $50.0 \%$ & 1 & $50.0 \%$ & 2 & $100.0 \%$ \\
\hline & Private-middle & 4 & $80.0 \%$ & 0 & $0.0 \%$ & 1 & $20.0 \%$ & 5 & $100.0 \%$ \\
\hline & Small & 0 & $0.0 \%$ & 0 & $0.0 \%$ & 0 & $0.0 \%$ & 0 & $0.0 \%$ \\
\hline \multirow[t]{3}{*}{2000} & State & 0 & $0.0 \%$ & 1 & $50.0 \%$ & 1 & $50.0 \%$ & 2 & $100.0 \%$ \\
\hline & Private-middle & 1 & $16.7 \%$ & 4 & $66.7 \%$ & 1 & $16.7 \%$ & 6 & $100.0 \%$ \\
\hline & Small & 0 & $0.0 \%$ & 0 & $0.0 \%$ & 0 & $0.0 \%$ & 0 & $0.0 \%$ \\
\hline \multirow[t]{3}{*}{2001} & State & 0 & $0.0 \%$ & 0 & $0.0 \%$ & 1 & $50.0 \%$ & 1 & $50.0 \%$ \\
\hline & Private-middle & 5 & $71.4 \%$ & 2 & $28.6 \%$ & 0 & $0.0 \%$ & 7 & $100.0 \%$ \\
\hline & Small & 0 & $0.0 \%$ & 0 & $0.0 \%$ & 0 & $0.0 \%$ & 0 & $0.0 \%$ \\
\hline \multirow[t]{3}{*}{2002} & State & 0 & $0.0 \%$ & 0 & $0.0 \%$ & 2 & $0.0 \%$ & 2 & $0.0 \%$ \\
\hline & Private-middle & 3 & $50.0 \%$ & 2 & $33.3 \%$ & 1 & $16.7 \%$ & 6 & $100.0 \%$ \\
\hline & Small & 0 & $0.0 \%$ & 0 & $0.0 \%$ & 0 & $0.0 \%$ & 0 & $0.0 \%$ \\
\hline \multirow[t]{3}{*}{2003} & State & 0 & $0.0 \%$ & 0 & $0.0 \%$ & 2 & $1.0 \%$ & 2 & $1.0 \%$ \\
\hline & Private-middle & 3 & $50.0 \%$ & 2 & $33.3 \%$ & 1 & $16.7 \%$ & 6 & $100.0 \%$ \\
\hline & Small & 0 & $0.0 \%$ & 0 & $0.0 \%$ & 0 & $0.0 \%$ & 0 & $0.0 \%$ \\
\hline \multirow[t]{3}{*}{2004} & State & 0 & $0.0 \%$ & 0 & $0.0 \%$ & 2 & $100.0 \%$ & 2 & $100.0 \%$ \\
\hline & Private-middle & 2 & $33.3 \%$ & 4 & $66.7 \%$ & 0 & $0.0 \%$ & 6 & $100.0 \%$ \\
\hline & Small & 0 & $0.0 \%$ & 0 & $0.0 \%$ & 0 & $0.0 \%$ & 0 & $0.0 \%$ \\
\hline \multirow[t]{3}{*}{2005} & State & 0 & $0.0 \%$ & 0 & $0.0 \%$ & 2 & $100.0 \%$ & 2 & $100.0 \%$ \\
\hline & Private-middle & 1 & $16.7 \%$ & 4 & $66.7 \%$ & 1 & $16.7 \%$ & 6 & $100.0 \%$ \\
\hline & Small & 0 & $0.0 \%$ & 0 & $0.0 \%$ & 0 & $0.0 \%$ & 0 & $0.0 \%$ \\
\hline \multirow[t]{3}{*}{2006} & State & 0 & $0.0 \%$ & 0 & $0.0 \%$ & 2 & $100.0 \%$ & 2 & $100.0 \%$ \\
\hline & Private-middle & 0 & $0.0 \%$ & 6 & $100.0 \%$ & 0 & $0.0 \%$ & 6 & $100.0 \%$ \\
\hline & Small & 1 & $100.0 \%$ & 0 & $0.0 \%$ & 0 & $0.0 \%$ & 1 & $100.0 \%$ \\
\hline \multirow[t]{3}{*}{2007} & State & 0 & $0.0 \%$ & 0 & $0.0 \%$ & 2 & $100.0 \%$ & 2 & $100.0 \%$ \\
\hline & Private-middle & 0 & $0.0 \%$ & 6 & $100.0 \%$ & 0 & $0.0 \%$ & 6 & $100.0 \%$ \\
\hline & Small & 2 & $100.0 \%$ & 0 & $0.0 \%$ & 0 & $0.0 \%$ & 2 & $100.0 \%$ \\
\hline \multirow[t]{3}{*}{2008} & State & 0 & $0.0 \%$ & 0 & $0.0 \%$ & 2 & $100.0 \%$ & 2 & $100.0 \%$ \\
\hline & Private-middle & 0 & $0.0 \%$ & 6 & $100.0 \%$ & 0 & $0.0 \%$ & 6 & $100.0 \%$ \\
\hline & Small & 2 & $100.0 \%$ & 0 & $0.0 \%$ & 0 & $0.0 \%$ & 2 & $100.0 \%$ \\
\hline \multirow[t]{3}{*}{2009} & State & 0 & $0.0 \%$ & 0 & $0.0 \%$ & 2 & $100.0 \%$ & 2 & $100.0 \%$ \\
\hline & Private-middle & 0 & $0.0 \%$ & 6 & $100.0 \%$ & 0 & $0.0 \%$ & 6 & $100.0 \%$ \\
\hline & Small & 4 & $100.0 \%$ & 0 & $0.0 \%$ & 0 & $0.0 \%$ & 4 & $100.0 \%$ \\
\hline \multirow[t]{3}{*}{2010} & State & 0 & $0.0 \%$ & 2 & $100.0 \%$ & 0 & $0.0 \%$ & 2 & $100.0 \%$ \\
\hline & Private-middle & 0 & $0.0 \%$ & 6 & $100.0 \%$ & 0 & $0.0 \%$ & 6 & $100.0 \%$ \\
\hline & Small & 1 & $16.7 \%$ & 4 & $66.7 \%$ & 1 & $16.7 \%$ & 6 & $100.0 \%$ \\
\hline \multirow[t]{3}{*}{2011} & State & 0 & $0.0 \%$ & 1 & $50.0 \%$ & 1 & $50.0 \%$ & 2 & $100.0 \%$ \\
\hline & Private-middle & 1 & $16.7 \%$ & 5 & $83.3 \%$ & 0 & $0.0 \%$ & 6 & $100.0 \%$ \\
\hline & Small & 2 & $25.0 \%$ & 5 & $62.5 \%$ & 1 & $12.5 \%$ & 8 & $100.0 \%$ \\
\hline
\end{tabular}


Cost Efficiency of Ethiopian Banks

\begin{tabular}{|l|l|l|l|l|l|l|l|l|l|}
\hline 2012 & State & 0 & $0.0 \%$ & 2 & $100.0 \%$ & 0 & $0.0 \%$ & 2 & $100.0 \%$ \\
\hline & Private-middle & 0 & $0.0 \%$ & 6 & $100.0 \%$ & 0 & $0.0 \%$ & 6 & $100.0 \%$ \\
\hline & Small & 0 & $0.0 \%$ & 6 & $75.0 \%$ & 2 & $25.0 \%$ & 8 & $100.0 \%$ \\
\hline 2013 & State & 1 & $50.0 \%$ & 0 & $0.0 \%$ & 1 & $50.0 \%$ & 2 & $100.0 \%$ \\
\hline & Private-middle & 3 & $50.0 \%$ & 2 & $33.3 \%$ & 1 & $16.7 \%$ & 6 & $100.0 \%$ \\
\hline & Small & 8 & $100.0 \%$ & 0 & $0.0 \%$ & 0 & $0.0 \%$ & 8 & $100.0 \%$ \\
\hline 2014 & State & 1 & $50.0 \%$ & 0 & $0.0 \%$ & 1 & $50.0 \%$ & 2 & $100.0 \%$ \\
\hline & Private-middle & 3 & $50.0 \%$ & 2 & $33.3 \%$ & 1 & $16.7 \%$ & 6 & $100.0 \%$ \\
\hline \multirow{2}{*}{2015} & Small & 10 & $100.0 \%$ & 0 & $0.0 \%$ & 0 & $0.0 \%$ & 10 & $100.0 \%$ \\
\hline & State & 1 & $50.0 \%$ & 0 & $0.0 \%$ & 1 & $50.0 \%$ & 2 & $100.0 \%$ \\
\hline & Private-middle & 4 & $66.7 \%$ & 2 & $33.3 \%$ & 0 & $0.0 \%$ & 6 & $100.0 \%$ \\
\hline & Small & 9 & $90.0 \%$ & 0 & $0.0 \%$ & 1 & $10.0 \%$ & 10 & $100.0 \%$ \\
\hline $1999-$ & State & 3 & $9.1 \%$ & 7 & $21.2 \%$ & 23 & $69.7 \%$ & 33 & $100.0 \%$ \\
\hline & Private-middle & 30 & $29.4 \%$ & 65 & $63.7 \%$ & 7 & 0.068627 & 102 & $100.0 \%$ \\
\hline & Small & 39 & $66.1 \%$ & 15 & $25.4 \%$ & 5 & 0.084746 & 59 & $100.0 \%$ \\
\hline
\end{tabular}

Source: Author's Computation 
Cost Efficiency of Ethiopian Banks

Table 1: CRS Model Slacks and Model Target for 2015

\begin{tabular}{|c|c|c|c|c|c|c|c|c|c|c|}
\hline DMU & Score & $\begin{array}{l}\text { Benchmark } \\
\text { (Lambda) }\end{array}$ & $\begin{array}{l}\text { Times as a } \\
\text { benchmark } \\
\text { for another } \\
\text { DMU }\end{array}$ & $\begin{array}{l}\text { Sum } \\
\text { Lambda }\end{array}$ & $\begin{array}{l}\text { Slack } \\
\text { Movement } \\
\text { Deposit) }\end{array}$ & $\begin{array}{l}\text { Projection } \\
\text { (Deposit) }\end{array}$ & $\begin{array}{l}\text { Slack } \\
\text { Movement } \\
\text { (Branch) }\end{array}$ & $\begin{array}{l}\text { Projection } \\
\text { (Branch) }\end{array}$ & $\begin{array}{l}\text { Slack } \\
\text { Movement } \\
\text { (fixed } \\
\text { asset) }\end{array}$ & $\begin{array}{l}\text { Projection } \\
\text { (fixed } \\
\text { asset) }\end{array}$ \\
\hline ABAY & 0.827289 & $\begin{array}{l}\text { CBE(0.003911); } \\
\text { CBO(0.285642) }\end{array}$ & 0 & 0.289553 & -573.862 & 3049.945 & -44.9036 & 44.09643 & -42.0301 & 63.10091 \\
\hline ADDIS & 0.897566 & $\begin{array}{l}\text { CBE(0.001588); } \\
\text { CBO(0.089158) }\end{array}$ & 0 & 0.090746 & -68.8627 & 1040.734 & -17.8774 & 14.12257 & -31.8654 & 20.3346 \\
\hline AIB & 0.880487 & $\begin{array}{l}\mathrm{CBE}(0.021367) \\
\mathrm{CBO}(1.538378)\end{array}$ & 0 & 1.559745 & -2020.83 & 16499.59 & 30.78651 & 237.7865 & -566.052 & 340.3707 \\
\hline BIRHAN & 0.79478 & $\begin{array}{l}\mathrm{CBE}(0.003005) \\
\mathrm{CBO}(0.234627)\end{array}$ & 0 & 0.237632 & -612.669 & 2455.226 & -40.9813 & 36.01873 & -3.15581 & 51.47119 \\
\hline $\mathrm{BOA}$ & 0.738583 & $\begin{array}{l}\mathrm{CBE}(0.016123) ; \\
\mathrm{CBO}(0.625727)\end{array}$ & 0 & 0.64185 & -2610.41 & 8507.752 & -33.0203 & 103.9797 & -722.948 & 151.3762 \\
\hline BUNNA & 0.868546 & $\begin{array}{l}\text { CBE }(0.003097) ; \\
\text { CBO }(0.315688)\end{array}$ & 0 & 0.318785 & -426.427 & 3074.613 & -34.4622 & 47.53783 & -20.4004 & 67.60656 \\
\hline $\mathrm{CBB}$ & 0.741777 & $\begin{array}{l}\mathrm{CBE}(0.009078) \\
\mathrm{CBO}(0.262548)\end{array}$ & 0 & 0.271626 & -1283.04 & 4128.867 & -76.1115 & 45.88845 & -103.144 & 67.54023 \\
\hline CBE & 1 & CBE(1.000000) & 16 & 1 & -0 & 241732 & -0 & 977 & -0 & 1740 \\
\hline $\mathrm{CBO}$ & 1 & $\mathrm{CBO}(1.000000)$ & 16 & 1 & -0 & 7367.888 & -0 & 141 & -0 & 197.086 \\
\hline DB & 0.826061 & $\begin{array}{l}\mathrm{CBE}(0.030239) \\
\mathrm{CBO}(1.242347)\end{array}$ & 0 & 1.272586 & -3350.88 & 16463.23 & 40.71453 & 204.7145 & -385.069 & 297.4652 \\
\hline DGB & 0.534218 & $\begin{array}{l}\mathrm{CBE}(0.000812) \\
\mathrm{CBO}(0.037221)\end{array}$ & 0 & 0.038034 & -348.749 & 470.5931 & -15.9582 & 6.041807 & -34.4188 & 8.749166 \\
\hline ENAT & 0.853185 & $\begin{array}{l}\mathrm{CBE}(0.000505) \\
\mathrm{CBO}(0.164083)\end{array}$ & 0 & 0.164587 & -234.296 & 1330.928 & 12.62869 & 23.62869 & -8.92153 & 33.21647 \\
\hline LIB & 0.895691 & $\begin{array}{l}\mathrm{CBE}(0.007084) \\
\mathrm{CBO}(0.310872)\end{array}$ & 0 & 0.317956 & -454.184 & 4002.816 & -37.2463 & 50.75372 & 8.182129 & 73.59413 \\
\hline
\end{tabular}

EJBE Vol. 6 No. 2/2016

Page 157 
Cost Efficiency of Ethiopian Banks

\begin{tabular}{|l|l|l|l|l|l|l|l|l|l|l|}
\hline NIB & 0.961288 & $\begin{array}{l}\text { CBE(0.014841); } \\
\text { CBO(0.798075) }\end{array}$ & 0 & 0.812917 & -306.346 & 9467.768 & 12.02864 & 127.0286 & -122.114 & 183.1135 \\
\hline OIB & 0.792048 & $\begin{array}{l}\text { CBE(0.004617); } \\
\text { CBO(0.63845) }\end{array}$ & 0 & 0.643069 & -1470.22 & 5820.068 & -57.4676 & 94.53237 & -48.9438 & 133.8632 \\
\hline UB & 0.88987 & $\begin{array}{l}\text { CBE(0.020297); } \\
\text { CBO(0.700313) }\end{array}$ & 0 & 0.72061 & -1004.5 & 10066.27 & -8.42567 & 118.5743 & -185.662 & 173.3387 \\
\hline WB & 0.912433 & $\begin{array}{l}\text { CBE(0.021861); } \\
\text { CBO(0.553734); }\end{array}$ & 0 & 0.575595 & -506.605 & 9364.339 & -19.5653 & 99.43468 & -493.855 & 147.1713 \\
\hline ZB & 0.913957 & $\begin{array}{l}\text { CBE(0.009175); } \\
\text { CBO(0.17274) }\end{array}$ & 0 & 0.181916 & -332.523 & 3490.737 & 21.32086 & 33.32086 & -18.6859 & 50.01008 \\
\hline
\end{tabular}

Source: Author's Computation 